\title{
INFLUENCE OF THE MANIPULATION OF INCUBATED JAPANESE QUAIL EGGS BY ASCORBIC ACID ON THE EMBRYO WEIGHT, HATCHABILITY AND HEMATOLOGICAL PARAMETERS OF THE CHICKS
}

\author{
A.A. Askar \\ Poultry Department, Faculty of Agriculture, Zagazig University, Zagazig, Egypt
}

\section{SUMMARY}

Three hundred and sixty eggs of Japanese quail birds were used in this trial; eggs were randomly assigned to four treatment groups, 90 eggs each. Eggs of the first group served as the control (untreated eggs), while the other three egg groups were sprayed with $10 \mathrm{~g} / \mathrm{L}$ of ascorbic acid (AA) solution twice daily by $50 \mathrm{ml}$ solution / 1000 egg during the last ten days of incubation period $\left(2^{\text {nd }}\right.$ group) or dipped in 4 or $8 \mathrm{~g} / \mathrm{l}$ of AA solution for two and half minutes (one time) pre incubation ( $3^{\text {ed }}$ and $4^{\text {th }}$ groups). Embryo weight percentage at the $15^{\text {th }}$ day of incubation and chick weight at hatch tended to be higher for eggs treated with AA than those of the control group eggs. This superiority was significant $(P<0.01)$ only at the $15^{\text {th }}$ day of incubation for the group sprayed with AA solution. Eggshell weight percentage tended to increase at the $8^{\text {th }}$ day of incubation for eggs dipped in $4 \mathrm{~g} / \mathrm{l}$ of AA solution or at $15^{\text {th }}$ day of incubation for those sprayed by AA solution. Eggs dipped in $8 \mathrm{~g} / \mathrm{l}$ of $A A$ solution had the highest percentage of lost weight comparing with those of the other groups. Eggs treated by $A A$ solution had significantly $(P<0.05)$ longer hatching periods than that of untreated eggs. Hatching percentage tended to increase in response to AA treatment. Embryonic mortality percentage was differed $(P<0.05)$ through 16-17 days of incubation in response to AA treatment, where the lowest and highest percentages of embryonic mortality were recorded in eggs dipped in $4 \mathrm{~g} / \mathrm{l}$ of $\mathrm{AA}$ solution and in untreated eggs. Hematological traits were differed $(P<0.05$ or 0.01$)$ in response to AA treatment. Hb content; PCV\% and RBC count for chicks of eggs sprayed by AA solution or those dipped in $4 \mathrm{~g} / \mathrm{l}$ of $\mathrm{AA}$ solution were higher than those dipped in $8 \mathrm{~g} / \mathrm{l}$ of $A A$ solution or eggs of the control group. Lymphocytes percentage was increased $(P<0.05)$ in chicks of eggs sprayed by AA solution or those dipped in $8 \mathrm{~g} / \mathrm{l}$ of $\mathrm{AA}$ solution than those of the control group or those dipped in $4 \mathrm{~g} / \mathrm{l}$ of AA solution. Eosinophils, basophils and monocytes percentages did not differ significantly due to AA treatment. Spraying Japanese quail eggs with AA solution $(10 \mathrm{~g} / \mathrm{l})$ or dipping in $4 \mathrm{~g} / \mathrm{l}$ of AA solution preincubation may be a good way to improve hatching performance and blood hematology and immunity of hatched chicks.

Keywords: Ascorbic acid, egg dipping, egg spraying, embryonic development, hatchability, blood hematology, Japanese quails

\section{INTRODUCTION}

Temperature; humidity; ventilation and turning during incubation period markedly influence the hatchability of fertile eggs and chick quality. The most dramatic effect of these factors on embryo development and hatchability is temperature (Ghonim, et al., 2009). Temperature control is probably the most critical factor for the embryonic development succession (Lundy, 1969). Suffering a developing embryo by temperature depends on three factors: incubator temperature; heat passing ability between both incubator and embryo and the metabolic heat production of the embryo itself (Meir and Ar, 1990). Most of poultry species have an optimum incubation temperature of 37 to $38^{\circ} \mathrm{C}$; any small deviations from this temperature can cause a major impact on embryo development and hatchability success (Wilson, 1991). High incubation temperature was found to enhance the embryonic growth, while low temperature retarded it. Chick embryos may be subjected to stress caused by excessive production of metabolic heat during the latter part of egg incubation, so the addition of AA solution as an anti-stress agent may be beneficial for embryos viability and protecting them from any stress during incubation (Tullett, 1990). Ascorbic acid is involved in a number of biochemical processes. It is necessary for biosynthesis of various vital compounds (i.e., collagen, carnitine, 1,25-dihydroxy vitamin D, adrenaline etc.), as well as, for the regulation of diverse reactions (secretion of corticosterone and regulation of body temperature) and activation of the immune system ( McDowell, 1989 and Kutlu, 2001). Furthermore, AA plays a critical role in vitamin $\mathrm{D}$ metabolism and it is required for the conversion of vitamin $\mathrm{D}$ into its metabolite form, which is essential for calcium regulation and calcification process (Sergeev et al., 1990 
and Bains, 1996). In addition, it is required for hydroxylation of proline residues necessary for the synthesis of pro-collagen, which is a precursor to bone formation. One of the basic biological functions of the eggshell for the domestic fowl chick is to allow adequate movement of water vapor and respiratory gases. Ascorbic acid is a weak acid and of high ability to interact with the eggshell cuticle (Burley and Vadehra, 1989). The literatures about the effect of AA treatment through dipping or spraying eggs on embryonic development; hatchability and blood haematology and immunity of poultry, especially Japanese quail are so rarely and had controversial reports. Therefore, this study was carried out to determine the beneficial effects of ascorbic acid treatment in Japanese quail eggs during incubation period on embryo weight, hatchability and some blood hematology and immunity of hatched chicks.

\section{MATERIALS AND METHODS}

The present study was carried out during winter 2011 to determine the beneficial effect of dipping or spraying eggs with AA solution on embryonic development, hatchability and some parameters of blood haematology and immunity of hatched chicks. Eggs were obtained from a commercial strain of healthy Japanese quail birds (Coturnix coturnix japonica) from a breeding colony of 11 weeks of age, which reared under standard husbandry conditions. Eggs were incubated at a temperature of $37.6 \pm 0.3^{\circ} \mathrm{C}$ and a relative humidity of $60-65 \%$ in a forced draught incubator.

Birds were fed ad-libtum a standard breed diet formulated to cover or exceed their requirements that containing $19.96 \%$ crude protein; $2890 \mathrm{Kcal} / \mathrm{kg}$ diet digestible energy; $2.58 \%$ calcium; $0.54 \%$ available phosphorous; $1.04 \%$ lysine and $0.69 \%$ sulfur amino acids. These values were calculated according to NRC (1994). Fresh water was available all time for birds.

Three hundred and sixty eggs of Japanese quail birds were used in this trial. Eggs were randomly assigned to four treatment groups, 90 eggs each. Eggs of the first group served as the control (non-treated eggs). The other three egg groups were sprayed during the last 10 days of incubation period with $10 \mathrm{~g} / 1$ of AA solution twice daily (at morning and at night) by $50 \mathrm{ml}$ solution / 1000 egg ( $2^{\text {nd }}$ group) or dipped one time pre incubation in 4 or $8 \mathrm{~g} / 1$ of AA solution for two and half minutes ( $3^{\text {ed }}$ and $4^{\text {th }}$ groups). Ascorbic acid solutions $\left(35-37^{\circ} \mathrm{C}\right)$ were freshly prepared by dissolving AA in distilled water and protected from light.
Traits measured in this study were: embryo weight and shell weight percentages at the $8^{\text {th }}$; $15^{\text {th }}$ and $17^{\text {th }}$ day of incubation; egg weight loss percentage at the $15^{\text {th }}$ day of incubation; hatchability from fertile eggs; hatching period (hrs) and embryonic mortality. Hatched chicks and accumulative embryonic mortality (unhatched eggs with live or dead embryos and dead hatched chicks) were counted. Hatched chicks were weighed, as well as, hatchability and embryonic mortality were calculated.

At hatch, blood samples from randomly selected six chicks per treatment were collected and transferred to vial tubes containing EDTA as anticoagulant. Hemoglobin content $(\mathrm{Hb})$; packed cell volume percentage $(\mathrm{PCV} \%)$ and red blood cells (RBC's) count were determined according to Winterobe (1967). Differential white blood cells (WBC's) counts were performed using standard avian guidelines according to Ritchie et al. (1994). Leukocyte cells (heterophils (H); lymphocytes (L); eosinophils; monocytes and basophiles) were counted in different microscopic fields in $200 \mathrm{WBC}$ 's by the same person, and the $\mathrm{H}: \mathrm{L}$ ratio was calculated (Gross and Siegel, 1986).

Data obtained from this study were statistically analyzed using one way ANOVA through the GLM procedures of SPSS program (1993) according to the following model:

$$
Y_{i j}=\mu+A_{i}+e_{i j}
$$

Where, $Y_{i j}=$ an observation on the $\mathrm{ij}^{\text {th }}$ egg; $\mu=$ general mean; $\mathrm{A}_{\mathrm{i}}=$ fixed effect of $i^{\text {th }}$ ascorbic acid, $i=1 ; 2 ; 3$ and 4 (control; spraying eggs by $10 \mathrm{~g} / \mathrm{l}$ of AA and dipping eggs in 4 or $8 \mathrm{~g} / \mathrm{l}$ of AA, respectively); and $\mathrm{e}_{\mathrm{ij}}$ $=$ error of the model, which included all the other effects not specified in the model. Differences among experimental groups were separated by Duncan's multiple range test (Duncan, 1955). Statistical analysis of traits presented as percentages was carried out for arcsine values of their estimates.

\section{RESULTS AND DISCUSSION}

Percentages of embryo weight at the $15^{\text {th }}$ day of incubation and chick weight at hatch (Tables 1 and 2) tended to be higher for eggs treated with AA solution than those of control eggs, especially eggs sprayed with AA solution showed the highest estimates at the $8^{\text {th }}$ and $15^{\text {th }}$ day of incubation and at hatch. However, this superiority was insignificant, except at the $15^{\text {th }}$ day of incubation. Similar results were reported in other studies by Zakaria et al. (1998) and Zakaria and Al-latif (1998), who reported that AA treatment during the latter stages of egg incubation is effective under heat 
stress condition. Zakaria and Al-anezi (1996) found that eggs injected by a dose of $3 \mathrm{mg}$ of $\mathrm{AA}$ at the $15^{\text {th }}$ day of incubation increased body weight of chicks compared with the control. Insignificant effects of AA treatment on embryonic weight percentage were obtained by Shafey (2002) and Karaly (2007), who found no significant difference in embryo weight due to dipping eggs of Gimmizah hens in AA solutions. Zakaria (2001) injected eggs at the $15^{\text {th }}$ day of incubation with $3 \mathrm{mg}$ of AA or dipped in $3 \%$ solution of AA for 3 minutes and reported that embryo weight and chick weight at hatch did not differ significantly between the treatments. In addition, Mohammed et al. (2011) indicated that there were no significant differences between treatments by dipping eggs in 5.0 or $10.0 \mathrm{~g}$ $\mathrm{AA} / 1$ solutions compared with the control group on embryonic weight percentage at the $10^{\text {th }} ; 18^{\text {th }}$ and $21^{\text {st }}$ day of incubation.

Most of eggshell weight percentages of eggs treated by AA solution were in similar values to those untreated ones. However, it showed a valuable insignificant increase at the $8^{\text {th }}$ day of incubation in eggs dipped in $4 \mathrm{~g} / \mathrm{l}$ of AA solution or at $15^{\text {th }}$ day of incubation in those sprayed by AA solution (Tables 1 and 2). The current results agree with those of Karaly (2007), who found that there were no significant differences between the controlled eggs and injected eggs with AA on eggshell weight. Also, Mohammed et al. (2011) showed that there were no significant effects on eggshell weight percentage between treatments of dipping solutions.

The effect of AA treatment on egg weight loss percentage was insignificant (Table 1), meanwhile eggs dipped in $8 \mathrm{~g} / \mathrm{l}$ of AA solution had the highest percentage of lost weight comparing with those of the other groups including the untreated one. The increase in egg weight loss percentage reached to the significant level due to the increase of AA solution at a concentration of 10 or $20 \mathrm{~g} / \mathrm{l}$ for dipping eggs for 2 minutes compared to the control group (Samak and Mahmoud, 2007). In addition, Mohammed et al. (2011) said that egg weight loss percentage was significantly affected by dipping eggs in AA solution for 2 minutes. Eggs dipped in $10 \mathrm{~g} \mathrm{AA} / 1$ increased the egg weight loss compared with those dipped in $5 \mathrm{~g} \mathrm{AA} / 1$ and non-dipped (the control) by 2.41 and $8.32 \%$, respectively. Insignificant effect of AA treatment on egg weight loss was observed also by Ghonim et al. (2009), who found that the differences between AA treatments during incubation period in egg weight loss were not significant. This increase in egg weight loss percentage may be due to the change of cuticle properties due to the interaction between eggshell cuticle and AA in the dipping solution. This interaction may cause a thinner cuticle or some physical changes in their morphology, resulting in increased eggshell conductance that increases the rate of water loss (Burley and Vadehra, 1989).

Eggs of treated groups by AA had significantly $(\mathrm{P}<0.05)$ longer hatching periods than that of untreated eggs (Table 2). Quail eggs dipped in $4 \mathrm{~g} / \mathrm{l}$ of AA solution recorded the longest period (430.3 hrs), then that of sprayed eggs $(423.0 \mathrm{hrs})$ comparing to the shortest one in untreated ones (420.0 hrs). Dipping eggs in 5.0 or $10.0 \mathrm{~g} / 1$ of AA solution insignificantly increased the length of incubation period (Mohammed et al., 2011). On contrary, Zakaria et al. (1998) reported that chicks of eggs injected with $2 \mathrm{mg}$ AA hatched earlier than chicks of the control groups. ElSheikh and El-Gammal (2000) found no significant effect of vitamin $\mathrm{C}$ supplementation on incubation period in eggs of Dandarawi hens.

Hatching percentage was increased insignificantly for all treated groups by AA in comparison with that of untreated one (Table $2)$. The highest percentage was observed in sprayed eggs by AA $(60.0 \%)$ versus the lowest one in untreated ones $(44.0 \%)$. In the same trend, benefits gains for AA treatments were observed by Ipek et al. (2004), who found that the injection of incubated eggs with 3.0 $\mathrm{mg} / \mathrm{egg}$ of AA at different times of incubation improved hatchability. In addition, Ghonim et al. (2008) reported that hatchability was significantly improved by dipping Muscovy duck eggs into ascorbic acid solution $20 \mathrm{~g} / 1$ for 2 minutes at the $14^{\text {th }}$ day of incubation period. Moreover, they found that hatchability was significantly improved by spraying Muscovy duck eggs with AA solution $30 \mathrm{~g} / \mathrm{l}$ during the last three weeks of incubation period. Ghonim et al. (2009) showed that hatchability percentage was significantly improved by about 22.97 and $32.44 \%$, respectively of AA dipping and spraying methods, while it was insignificantly improved by about $8.8 \%$ by the injection method as compared to the control. Spraying AA increased hatchability percentage by 7.7 and $21.7 \%$ as compared to dipping or injection treatments by AA, respectively. Mohammed et al. (2011) indicated that hatchability of hen fertile eggs was significantly improved by dipping eggs in $5.0 \mathrm{~g}$ AA/1 solution (88.92\%) followed by those dipped in $10.0 \mathrm{~g}$ AA/1 solution (87.21\%) compared with the control group (83.63\%). Controversial findings were mentioned by Zakaria and Al-Anezi (1996), who found that a dose of $3 \mathrm{mg}$ of $\mathrm{AA}$ at the $15^{\text {th }}$ day of incubation improved hatchability compared with the control, while there was a decrease in 
hatchability compared to control when eggs were injected with $12 \mathrm{mg}$ of AA at the $15^{\text {th }}$ day of incubation. Zakaria (2001) injected eggs at the $15^{\text {th }}$ day of incubation with $3 \mathrm{mg}$ of AA or dipped eggs in $3 \%$ solution of AA for 3 minutes and reported that hatchability did not differ significantly between the treatments.

The improvement of hatchability may be due to decreasing the embryonic mortality where AA may be regarded as an anti-stress agent, which led to the reduction of corticosterone which in turn has a negative effect on collagen synthesis and metabolism of minerals and vitamin D (Pardue and Thaxton, 1986). The superiority of spraying method in hatchability improvement may be due to the higher effect of AA on eggshell conductance, which is essential for the exchange of respiratory gases during incubation. Moreover, the improvement of hatchability percentage may be due to the increasing in eggshell conductance as a result to the interaction between AA solution with eggshell cuticle that changes its properties, which may have cause a thinner cuticle or some physical changes in their morphology (Burley and Vadehra, 1989).

Embryonic mortality during the first period of incubation (1-15 days) did not differ significantly in response to AA treatment (Table 2), however the lowest mortality was recorded in eggs sprayed by AA $(22.0 \%)$ compared to the other treated groups or untreated one (30-38\%). On the other hand, there were significant differences $(\mathrm{P}<0.05)$ in embryonic mortality through the second period of incubation (16-17 days) in response to AA treatment. The lowest and highest values of embryonic mortality through the second period were recorded in eggs dipped in $4 \mathrm{~g} / \mathrm{l}$ of AA and in untreated eggs (6.0 and 26.0, resp.). These results were fairly corresponded to those found by Tag El-Din et al. (2004), who found that the injection of incubated eggs with 3 mg/egg of AA decreased embryonic mortality. Also, Ghonim et al. (2008) found that embryonic mortality was significantly decreased by dipping Muscovy duck eggs into $20 \mathrm{~g}$ of $\mathrm{AA} / 1$ for 2 minutes at the $14^{\text {th }}$ day of incubation or sprayed eggs with $30 \mathrm{~g}$ of AA/1 twice daily during the last three weeks of hatching process. Ghonim et al. (2009) reported that AA treatment for eggs during incubation period had lower embryonic mortality than that of the control group. Embryonic mortality was significantly decreased by about 44.15 and $62.36 \%$, respectively for eggs dipped or sprayed by AA. Spraying eggs by AA resulted in decreasing the embryonic mortality by 32.60 and $54.70 \%$ than those dipped or injected by AA, respectively. Mohammed et al. (2011) reported that there were significant differences among treatments of dipping eggs in AA on embryonic mortality at 1-18, 19-21 and 1-21 days of incubation, whereas dipping eggs in 5 $\mathrm{g} / \mathrm{l}$ of AA for 2 minutes reduced embryonic mortality compared with the other treatments by 13.31 and $32.25 \%$ for eggs dipped in $10 \mathrm{~g}$ of $\mathrm{AA} / 1$ or control eggs, respectively. In contrast, Zakaria and Al-anezi (1996) found that there was a significant increase in dead embryos compared to control for eggs injected with $12 \mathrm{mg} \mathrm{AA}$ at the $15^{\text {th }}$ day of incubation.

The decrease in embryonic mortality may be due to that AA acts as an anti-stress agent as mentioned previously (Pardue and Thaxton, 1986; McDowell, 1989 and Kutlu, 2001). In addition, ascorbic acid is essential to maintain the normal development of immune response during physiological stress in the chicken. Moreover, ascorbic acid effects on the level of energy available to embryo development and to protect them from any stresses during incubation (Tag El-Din et al., 2004). Spraying method of AA could improve the biological functions of the eggshell to allow adequate movement of water vapor and respiratory gases and increase the ability of AA as a weak acid to interact with the eggshell cuticle, which helps embryos to break eggshell at hatch (Tullett, 1990).

Haematological traits presented in Table (3) showed significant differences in response to AA treatment $(\mathrm{P}<0.05$ or 0.01$)$. Values of $\mathrm{Hb}$ content; PCV \% and RBC's count for chicks of eggs sprayed by AA solution or those dipped in $4 \mathrm{~g} / \mathrm{l}$ of AA solution were in nearly similar magnitude and higher than those of eggs dipped in $8 \mathrm{~g} / \mathrm{l}$ of AA solution or eggs of the control group (Table 3). Similar results were reported by Kontecka et al. (2006) who found that the blood of hatched ducklings from ducks fed supplemented diets with AA by 500 $\mathrm{mg} / \mathrm{kg}$ was high in hemoglobin content. Ghonim et al. (2009) indicated that AA treatment during incubation period of duck eggs resulted in an increase in the hemoglobin content. On the other hand, ducklings derived from AA treatment by dipping, spraying and injection methods did not differ significantly with regard to hemoglobin content in the blood ducklings.

Results of counts of different white blood cells $(\%)$ in hatched chicks presented in Table (4) show that heterophils percentage and H/L ratio were insignificantly decreased, while lymphocytes percentage was significantly $(\mathrm{P}<0.05)$ increased in chicks of eggs sprayed by AA solution or dipped in $8 \mathrm{~g} / 1$ of $\mathrm{AA}$ solution than those of untreated eggs or those dipped in $4 \mathrm{~g} / 1$ of AA solution. Eosinophils, basophils and monocytes percentages did not differ significantly due to the treatment by AA. These results may ensure that AA acted as a 
good anti-stressors agent. Since, the alteration in temperature degree during incubation or the high effort exerted by chicks during eggshell breakage may cause some stress on the embryo. Viviane et al. (2010) showed that lymphocytes and heterophils were the unique cell types influenced by incubation temperature, whereas heterophil values and $\mathrm{H} / \mathrm{L}$ ratio were higher and lymphocyte values were lower when the incubation temperature increased. They added that all these cell types are related with the natural cellular immunity of the birds, especially in egg and immediately after the hatchability. Whereas, during these phases, birds did not develop acquired immunity yet (Kogut et al., 1998). Heterophilia has been considered the response to light and moderate stress in birds (Maxwell et al., 1992), while $\mathrm{H} / \mathrm{L}$ ratio is a known index to measure stress in chickens (Gross and Siegel, 1983). Furthermore, the value of $\mathrm{H} / \mathrm{L}$ ratio was higher for chicks that needed more time to hatch, i.e. the duration of eggshell breakage (Bautista-Ortega et al., 1997). On the other hand, Ghonim et al. (2009) indicated that AA treatment during incubation period of duck eggs resulted in an increase in eosinophils, basophils and monocytes percentages at hatch. In addition, ducklings derived from AA treatment (dipping, spraying and injection) were characterized by high basophils percentages when compared with the control group. In AA spraying method, $\mathrm{H} / \mathrm{L}$ ratio was found to be significantly higher than in the control group. Ducklings derived from AA treatment by dipping, spraying and injection did not differ significantly with regard to the percentage of heterophils, lymphocytes, eosinophils and monocytes in blood ducklings.

\section{CONCLUSION}

The obtained results showed that spraying Japanese quail eggs by $10 \mathrm{~g} / \mathrm{l}$ of AA solution twice daily during the last 10 days of incubation period or dipping in $4 \mathrm{~g} / 1$ of AA solution pre-incubation may be a good way to improve hatching performance and blood hematology; immunity and viability of hatched chicks without adverse effects.

\section{REFERENCES}

Bains, B.S., 1996. The role of vitamin C in stress management. Misset World Poult. Sci., 12: 38-42.

Bautista-Ortega, J., G.W. Robertson and M.H. Maxwell, 1997. Studies of the relationship between hatching times and pre-ascitic lesions in young broilers. Br. Poult. Sci., 38 (supl.): 46.
Burley, R.W. and D.V. Vadehra, 1989. The eggshell and shell membranes properties and synthesis. In: R.W. Burley and D.V. Vadehra (Eds).The Avian Egg: Chemistry and Biology, John Wiley, New York, USA, 25-64.

Duncan, D.B., 1955. Multiple range and multiple F. tests. Biometrics, 11: 1-42.

El-Sheikh, T.M. and A.M. El-Gammal, 2000. Effect of the holding temperature, holding period as well as vitamin $\mathrm{C}$ supplementation on hatching traits of Dandarawi eggs. Egypt. Poult. Sci. J., 20: 839-855.

Ghonim, A.I.A., A.L. Awad, M.H. A. Fattouh and A.M. El- Shhat, 2009. Comparative study of ascorbic acid treatment methods on hatchability traits and growth performance of ducklings Egypt. Poult. Sci., 29: 1085-1099.

Ghonim, A.I.A., A.L. Awad, M.H.A. Fatouh, A.M. El-Shhat and Kh.A.A. Ali, 2008. Effect of dipping and spraying hatching eggs of Muscovy duck by ascorbic acid solutions during incubation period on hatchability traits. Egypt. Poult. Sci., 28: 283-293.

Gross, W.B. and H.S. Siegel, 1983. Evaluation of the heterophil/lymphocyte ratio as a measure of stress in chickens. Avian Dis., 27: 972-979.

Gross, W.B. and P.B. Siegel, 1986. Effects of initial and second periods of fasting on heterophil/lymphocyte ratios and body weight. Av. Dis., 30: 345-346.

Ipek, A., U. Sahan and B. Yllmaz, 2004. The effect of in ovo ascorbic acid and glucose injection in broiler breeder eggs on hatchability and chick weight. Arch. Geflügelk., 68: 132-135.

Karaly, M.A.M., 2007. The effect of ascorbic acid on some physiological and productive performance of laying local strains. Ph.D. Thesis, Fac. of Agric, Alexandaria univ. Egypt.

Kogut, M.H., K. Lowry, R.B. Moyses, R. Bowden, K. Genovese and D. Deloach, Jr., 1998. Lympholineaugmented activation of avian heterophils. Poult. Sci., 77: 964-971.

Kontecka, H., S. Nowaczewski, J. Ksiazkiewicz and A. Rosinski, 2006. The effect of supplementing feed with vitamin $\mathrm{C}$ on the haematological indices of ducks and their offspring. J. Anim. Feed Sci., 15: 455-462.

Kutlu, H.R., 2001. Influences of wet feeding and supplementation with ascorbic acid on performance and carcass composition of broiler chicks exposed to a high ambient temperature. Arch. Anim. Nutri., 54: 127139. 
Lundy, H., 1969. A review of the effects of temperature, humidity, turning and gaseous environment in the incubator on the hatchability of the hens egg. 143-176 in: The fertility and hatchability of the hens egg. Carter, T.C. and B.M. Freeman, Oliver and Boyd, Edinburgh, Scotland.

Maxwell, M.H., G.W. Robertson, M.A. Mitchell and A.J. Carlisle, 1992. The fine structure of broiler chicken blood cells, with particular reference to basophils, after severe heat stress. Comp. Haematol. Int., 2: 190-200.

McDowell, L.R., 1989. Comparative aspects to human nutrition. Vitamin A and E. In: L.R. McDowell (Ed.): Vitamins in Animal Nutrition. Academic Press, London, UK, 93-131.

Meir, M. and A. Ar, 990. Gas pressures in the air cell of the ostrich egg prior to piping as related to oxygen consumption, eggshell gas conductance and egg temperature. Condor, 92: 556-563.

Mohammed, K.A., Attiat.El-Boghdady, M.A.H. Soliman, M.A. Abd-Al-Galil and N.M. Abd-Al-Aleem, 2011. The effect of both pre-incubation dipping eggs in vitamin $\mathrm{c}$ and cooling eggs during incubation period on embryonic and hatchability parameters in two local chicken strains. Egypt. Poult. Sci., 31: 379-392.

NRC, 1994. Nutrient Requirements of Poultry. 9th rev. ed. National Academy Press, Washington, DC.

Pardue, S.L. and J.P. Thaxton, 1986. Ascorbic acid in poultry: A review. World's Poult. Sci. J., 42: 107-123.

Ritchie, B.W., J. G.Harrison and R.L. Harrison, 1994. Avian Medicine. Winger's Publishing Inc, Florida, USA, 176-198.

Samak, H.R. and R.M. Mahmoud, 2007. Effect of ascorbic or citric acid solutions on egg shell conductance and incubation traits of Sinai eggs. J. Agric. Sci. Mansoura univ. 32 (10): 8111-8118.

Sergeev, I.N., Y.P. Arkhapchev and V.D. Spirichev, 1990. Ascorbic acid effects on vitamin $\mathrm{D}$ hormone metabolism and binding in guinea pigs. J. Nutr., 120: 11851190.

Shafey, T.M., 2002. Eggshell conductance; embryonic growth; hatchability and embryonic mortality of broiler breeder eggs dipped into ascorbic acid solution. $\mathrm{Br}$. Poult. Sci. 43: 135-140.

SPSS program, 1993. Statistical Package for Social Science, SPSS for Windows. Computer Program, version, 5-1.

Tag El-Din, H.T., A.A. El-Serwy, E.H. AbouEgla, I.A. Homuda and A.L. Awad, 2004. Effect of in-ovo injection material in duck eggs on hatchability, embryonic mortality and ducklings performance. Egyptian $\mathrm{J}$. Anim. Prod. 41, Suppl. Issue, Nov: 459469.

Tullett, S.C., 1990. Science and the art of incubation. Poul. sci., 69: 1-15.

Viviane De Souza Morita, Isabel Cristina Boleli and João Ademir de Oliveira, 2010. Hematological and incubation parameters of chicks from young breeders eggs: Variation with sex and incubation temperature. International Journal of Poultry Science 9 (6): 606-612.

Wilson, H.R., 1991. Physiological requirements of the developing embryo: Temperature and turning. Chapter 9, 145156 In: Avian incubation. S.G. Tullet, ed., Butterworth-Heinemann, London, UK.

Winterobe, M.M., 1967. Clinical Hematology; 6th ed. London: Kimpton.

Zakaria, A.H., 2001. Effect of ascorbic acid treatment during egg incubation on preand post-hatching development of broiler chickens. Damascus University Journal of Agriculture Science, 17 (2): 118-130.

Zakaria, A.H. and M.A. Al-Anezi, 1996. Effect of ascorbic acid and cooling during incubation on hatchability, culling, mortality and body weight of broiler chickens. Poult. Sci., 75: 1204-1209.

Zakaria, A.H., A.A. Al-latif and M.A. Alanezi, 1998. Effect of ascorbic acid on embryonic development, hatch time and growth of extended delayed placement of broiler chickens. Arch. Geflügelk., 62: 1115.

Zakaria, A.H., and A.A. Al-latif, 1998. Effect of ascorbic acid treatment during egg incubation and after hatch on embryonic development, hatch time, and body weight changes of posthatch incubation time of broiler chicken. Arch. Geflügelk., 62: 176182. 
Table 1. Effect of ascorbic acid on percentages of embryo weight and eggshell weight at $8^{\text {th }}$ or $15^{\text {th }}$ day and egg weight loss at $15^{\text {th }}$ day of incubation

\begin{tabular}{|c|c|c|c|c|c|c|c|}
\hline \multirow[t]{2}{*}{ Items } & & \multicolumn{5}{|c|}{ Traits } & \multirow[b]{2}{*}{$\begin{array}{c}\text { Egg weight } \\
\text { loss \% } \\
(15 \mathrm{~d})\end{array}$} \\
\hline & & $\begin{array}{c}\text { Initial } \\
\text { egg } \\
\text { weight }\end{array}$ & $\begin{array}{c}\text { Embryo } \\
\text { weight \% } \\
(8 d)\end{array}$ & $\begin{array}{l}\text { Eggshell } \\
\text { weight \% } \\
(8 d)\end{array}$ & $\begin{array}{c}\text { Embryo } \\
\text { weight \% } \\
(15 \mathrm{~d})\end{array}$ & $\begin{array}{c}\text { Eggshell } \\
\text { weight \% } \\
(15 \mathrm{~d})\end{array}$ & \\
\hline \multirow{3}{*}{ Control } & & $\mathrm{ns}$ & $\mathrm{ns}$ & ns & $* *$ & ns & ns \\
\hline & $\bar{X}$ & 10.24 & 8.74 & 14.10 & $45.45^{\mathrm{b}}$ & 12.70 & 12.21 \\
\hline & SE & 0.15 & 0.22 & 0.83 & 0.73 & 0.37 & 0.48 \\
\hline \multirow{2}{*}{$\begin{array}{l}\text { Spraying by } \\
\text { AA }(10 \mathrm{~g} / 1)\end{array}$} & $\bar{X}$ & 10.28 & 8.80 & 14.49 & $51.94^{\mathrm{a}}$ & 13.14 & 11.98 \\
\hline & SE & 0.11 & 0.32 & 1.98 & 0.77 & 0.92 & 0.53 \\
\hline \multirow{3}{*}{$\begin{array}{l}\text { Dipping in } \\
\text { AA }(4 \mathrm{~g} / 1)\end{array}$} & $\bar{X}$ & 10.37 & 8.21 & 16.70 & $50.43^{\mathrm{a}}$ & 12.68 & 12.91 \\
\hline & $\mathrm{SE}$ & 0.19 & 0.25 & 1.13 & 1.78 & 0.90 & 0.69 \\
\hline & $\bar{X}$ & 10.34 & 8.36 & 14.23 & $51.24^{\mathrm{a}}$ & 12.96 & 13.15 \\
\hline $\begin{array}{l}\text { Dipping in } \\
\text { AA }(8 \mathrm{~g} / 1)\end{array}$ & $\mathrm{SE}$ & 0.14 & 0.30 & 1.23 & 1.41 & 0.99 & 0.68 \\
\hline
\end{tabular}

Table 2. Effect of ascorbic acid on hatching parameters and embryonic mortality

\begin{tabular}{|c|c|c|c|c|c|c|c|}
\hline \multirow[t]{3}{*}{ Items } & & \multicolumn{6}{|c|}{ Traits } \\
\hline & & \multirow{2}{*}{$\begin{array}{c}\text { Chick } \\
\text { weight at } \\
\text { hatch } \%\end{array}$} & \multirow{2}{*}{$\begin{array}{l}\text { Eggshell } \\
\text { weight } \\
\%(17 d)\end{array}$} & \multirow{2}{*}{$\begin{array}{c}\text { Hatching } \\
\text { period } \\
(\mathrm{hrs})\end{array}$} & \multirow{2}{*}{$\begin{array}{c}\text { Hatching \% } \\
\text { of fertile } \\
\text { eggs }\end{array}$} & \multicolumn{2}{|c|}{ Embryonic mortality \% } \\
\hline & & & & & & $(1-15 d)$ & $(16-17 d)$ \\
\hline \multirow{3}{*}{ Control } & & ns & ns & $*$ & ns & ns & $*$ \\
\hline & $\bar{X}$ & 72.47 & 9.22 & $420.0^{\mathrm{b}}$ & 44.00 & 30.00 & $26.00^{\mathrm{a}}$ \\
\hline & $\mathrm{SE}$ & 1.12 & 0.23 & 2.85 & 7.09 & 6.55 & 6.27 \\
\hline \multirow{2}{*}{$\begin{array}{l}\text { Spraying by } \\
\text { AA }(10 \mathrm{~g} / \mathrm{l})\end{array}$} & $\bar{X}$ & 75.40 & 9.21 & $423.0^{\mathrm{ab}}$ & 60.00 & 22.00 & $18.00^{\mathrm{ab}}$ \\
\hline & SE & 1.05 & 0.19 & 3.18 & 7.00 & 5.92 & 5.49 \\
\hline \multirow{3}{*}{$\begin{array}{l}\text { Dipping in } \\
\text { AA (4 g/l) }\end{array}$} & $\bar{X}$ & 74.92 & 9.36 & $430.3^{\mathrm{a}}$ & 56.00 & 38.00 & $6.00^{\mathrm{b}}$ \\
\hline & $\mathrm{SE}$ & 1.29 & 0.24 & 3.3 & 7.09 & 6.93 & 3.39 \\
\hline & $\bar{X}$ & 74.32 & 9.41 & $421.0^{\mathrm{b}}$ & 54.00 & 34.00 & $12.00^{\mathrm{ab}}$ \\
\hline $\begin{array}{l}\text { Dipping in } \\
A A(8 g / 1)\end{array}$ & $\mathrm{SE}$ & 1.63 & 0.40 & 2.4 & 7.12 & 6.77 & 4.64 \\
\hline
\end{tabular}

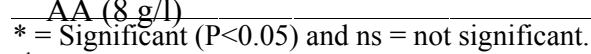

${ }^{a, b,}:$ means in the same column bearing different superscripts are significantly different $(\mathrm{P} \leq 0.05)$.

Table 3. Effect of ascorbic acid on hemoglobin content $(\mathrm{Hb})$; packed cell volume percentage (PCV\%) and red blood cells (RBC's) count.

\begin{tabular}{ccccc}
\hline \multirow{2}{*}{ Items } & & \multicolumn{3}{c}{ Traits } \\
\cline { 3 - 4 } Control & $\bar{X}$ & $\mathrm{Hb}(\mathrm{g} / \mathrm{dl})$ & PCV\% & $\mathrm{RBC}^{\prime} \mathrm{s}\left(\times 10^{6} / \mathrm{mm}^{3}\right)$ \\
\hline Spraying by AA (10 & $\bar{X}$ & $10.63^{\mathrm{b}}$ & $25.31^{\mathrm{b}}$ & $2.22^{\mathrm{b}}$ \\
g/l) & $\mathrm{SE}$ & 0.52 & 2.48 & 0.11 \\
& $\mathrm{SE}$ & $12.97^{\mathrm{a}}$ & $32.32^{\mathrm{a}}$ & $2.65^{\mathrm{a}}$ \\
Dipping in AA (4 g/l) & $\bar{X}$ & 0.61 & 1.67 & 0.11 \\
& $\mathrm{SE}$ & $13.23^{\mathrm{a}}$ & $34.46^{\mathrm{a}}$ & $2.50^{\mathrm{a}}$ \\
Dipping in AA $(8 \mathrm{~g} / \mathrm{l})$ & $\bar{X}$ & 0.49 & 1.78 & 0.12 \\
\hline
\end{tabular}

$*$ Significant $(\mathrm{P}<0.05)$ and $* *=$ highly significant $(\mathrm{P}<0.01)$.

${ }^{a, b,}$ :means in the same column bearing different superscripts are significantly different $(\mathrm{P} \leq 0.05)$. 
Table 4. Effect of ascorbic acid on differential counts of white blood cells (\%) in hatched chicks

\begin{tabular}{|c|c|c|c|c|c|c|c|}
\hline \multirow{2}{*}{ Items } & & \multicolumn{6}{|c|}{ Traits } \\
\hline & & Heterophils & Lymphocyts & Eosinophils & Basophils & Monocytes & $\mathrm{H} / \mathrm{L}$ \\
\hline \multirow{3}{*}{ Control } & & ns & $*$ & ns & ns & ns & ns \\
\hline & $\bar{X}$ & 23.83 & $68.33^{\mathrm{b}}$ & 3.83 & 1.33 & 2.67 & 0.35 \\
\hline & SE & 1.01 & 0.99 & 0.31 & 0.42 & 0.21 & 0.02 \\
\hline \multirow{2}{*}{$\begin{array}{l}\text { Spraying by } \\
\text { AA }(10 \mathrm{~g} / \mathrm{l})\end{array}$} & $\bar{X}$ & 22.0 & $71.17^{\mathrm{a}}$ & 3.50 & 1.33 & 2.00 & 0.31 \\
\hline & SE & 0.37 & 0.87 & 0.22 & 0.21 & 0.26 & 0.01 \\
\hline \multirow{3}{*}{$\begin{array}{l}\text { Dipping in } \\
\text { AA }(4 \mathrm{~g} / 1)\end{array}$} & $\bar{X}$ & 23.83 & $68.50^{\mathrm{b}}$ & 4.00 & 1.17 & 2.50 & 0.35 \\
\hline & SE & 0.70 & 0.85 & 0.26 & 0.31 & 0.22 & 0.01 \\
\hline & $\bar{X}$ & 22.17 & $70.83^{\mathrm{ab}}$ & 3.67 & 1.50 & 1.83 & 0.31 \\
\hline Dipping in & SE & 0.95 & 0.87 & 0.42 & 0.34 & 0.31 & 0.02 \\
\hline
\end{tabular}

$* \stackrel{\mathrm{A} A \text { Significant }}{(\mathrm{P}<0.05)} \overline{\text { and } \mathrm{ns}=\text { not significant. }}$

${ }^{\mathrm{a}, \mathrm{b},}$ :means in the same column bearing different superscripts are significantly different $(\mathrm{P} \leq 0.05)$.

تأثير معالجة بيض السمان الياباني بحامض الأسكوربيك علي وزن الجنين ونسبة الفقس ومقاييس الام

تم استخدام ثلاثمائة وسنون بيضة لطيور السمان الياباني في هذة التجربة، حيث تم توزيع البيض عشو ائيا الي اربع مجمو عات بكل

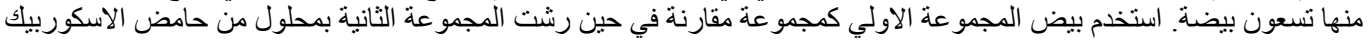

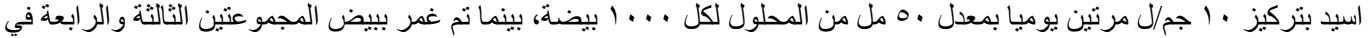

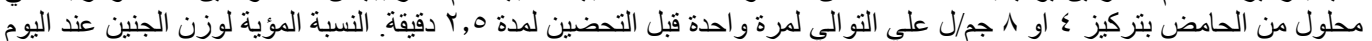

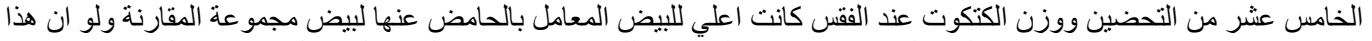

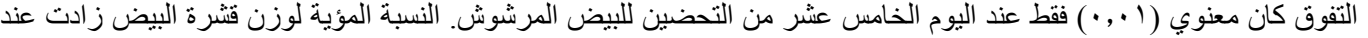

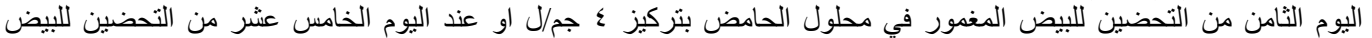

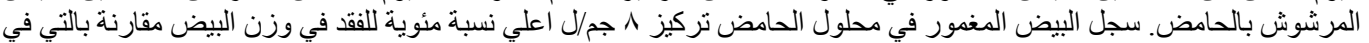

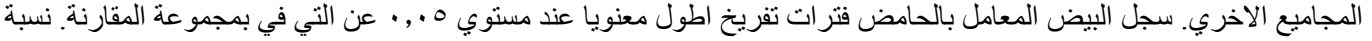

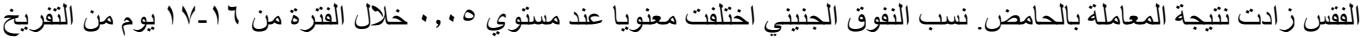

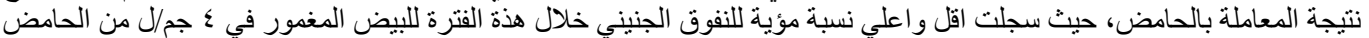

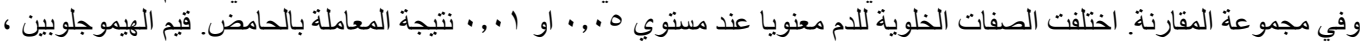

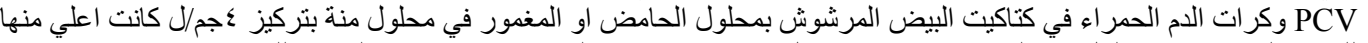

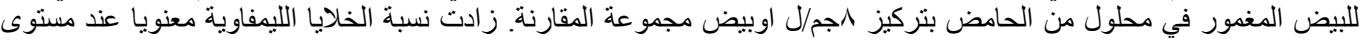

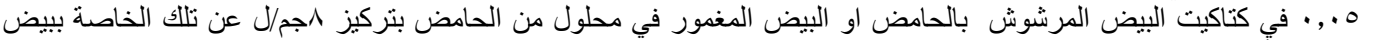

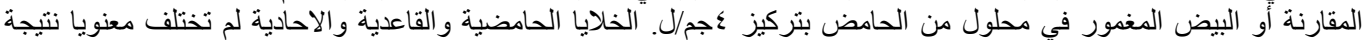

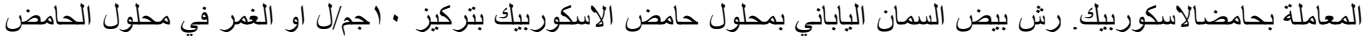
بتركيز عجم/ل قبل التفريخ ربما يكون طريقة جيدة لتحسين عملية التفريخ و الخصائص الخلوية للام و المناعة للكتاكيت الفاقسة. 